\title{
Use of Detailed Topographic Map Evidence of the Southeast Wyoming Gangplank Area to Compare Two Fundamentally Different Geomorphology Paradigms, USA
}

\author{
Eric Clausen \\ Independent Researcher, Jenkintown, PA, USA \\ Email: eric2clausen@gmail.com
}

How to cite this paper: Clausen, E. (2020) Use of Detailed Topographic Map Evidence of the Southeast Wyoming Gangplank Area to Compare Two Fundamentally Different Geomorphology Paradigms, USA. Open Journal of Geology, 10, 261-279.

https://doi.org/10.4236/ojg.2020.104014

Received: March 3, 2020

Accepted: March 31, 2020

Published: April 3, 2020

Copyright $\odot 2020$ by author(s) and Scientific Research Publishing Inc. This work is licensed under the Creative Commons Attribution International License (CC BY 4.0).

http://creativecommons.org/licenses/by/4.0/ (c) (i) Open Access

\begin{abstract}
Drainage divides along a southern Laramie Range crest area and in the nearby southeast Wyoming Gangplank area (as observed on detailed topographic maps) suggest present-day drainage routes in the Cheyenne Tablelands region originated as headward erosion of south-oriented valleys (now the downstream Lodgepole, Crow, and Lone Tree Creek valleys) from an actively eroding northeast-oriented South Platte River valley captured flood flow in the south half of a large east-oriented anastomosing channel complex while headward erosion of a north-oriented valley (now the downstream Horse Creek valley) from the southeast-oriented North Platte River valley captured the north half of the same large anastomosing channel complex. The Gangplank, which today serves as a low gradient ramp of Tertiary Ogallala Formation sediments leading from the Great Plains to the Laramie Range erosion surface, is located along the Crow Creek-Lone Tree Creek drainage divide and low points along that divide (referred to here as divide crossings) suggest, prior to headward erosion of what is now its south-oriented downstream Lone Tree Creek valley, upstream east-oriented Lone Tree Creek drainage routes were intertwined with east-oriented Crow Creek drainage routes, which today flow much further in an east direction (than east-oriented upstream Lone Tree Creek drainage routes) before also turning in a south direction to reach the South Platte River. The ability of the commonly accepted regional geomorphology paradigm to explain this topographic map evidence is then compared with a fundamentally different and new regional geomorphology paradigm's ability to explain the same evidence. While both paradigms offer possible explanations the new paradigm, which requires headward erosion of the valleys to have occurred as massive continental ice sheet
\end{abstract}


melt water floods crossed the region, explains much more of the drainage system evidence and also permits much more detailed explanations.

\section{Keywords}

Anastomosing Channel Complex, Cheyenne Tablelands, Crow Creek,

Drainage Divide, Great Plains, Laramie Range, Lone Tree Creek,

South Platte River

\section{Introduction}

\subsection{Statement of the Problem}

The interpretation of detailed topographic maps to determine previous drainage patterns (that existed prior to modern-day drainage) is a powerful, but rarely used research tool. The map interpretation technique begins by locating low points along drainage divides (referred to in this paper as divide crossings) where water once flowed in one direction or the other across what is now a drainage divide and then uses map evidence to determine the former flow direction, the nature of the flow, and why the flow direction changed so as to create the drainage divide. While detailed topographic maps covering most North American regions have been available for at least fifty years the published geomorphology literature rarely describes such studies, perhaps because the commonly accepted geomorphology paradigm does not offer good explanations for what the detailed topographic maps show. Scientific paradigms according to Thomas Kuhn [1] are frameworks of rules governing how researchers in a specific discipline conduct their research with each discipline's accepted paradigm having been selected based on its ability to explain observed evidence and to open up new research opportunities. Kuhn notes most scientific research is normal science in which the discipline's accepted paradigm is fleshed out and not questioned, but that paradigms also identify anomalous evidence, which an accepted paradigm cannot explain. Anomalous evidence according to Kuhn is dealt with in one of three ways; first the paradigm eventually explains it and the accepted paradigm continues without serious interruption; second, the anomalous evidence is described and shelved for future consideration; and third, the anomalous evidence leads to a new paradigm and a battle over which paradigm to use.

Several drainage features in the the North and South Platte River drainage areas seen in Figure 1 represent large-scale anomalous evidence the commonly accepted regional geomorphology paradigm (accepted paradigm) has yet to explain. For example, the accepted paradigm usually assumes Wyoming mountain ranges (such as the Laramie Mountains) developed during Eocene time and was then eroded as Oligocene and Miocene sediments filled structural basins between the mountain ranges to produce an eastward sloping surface and drainage 


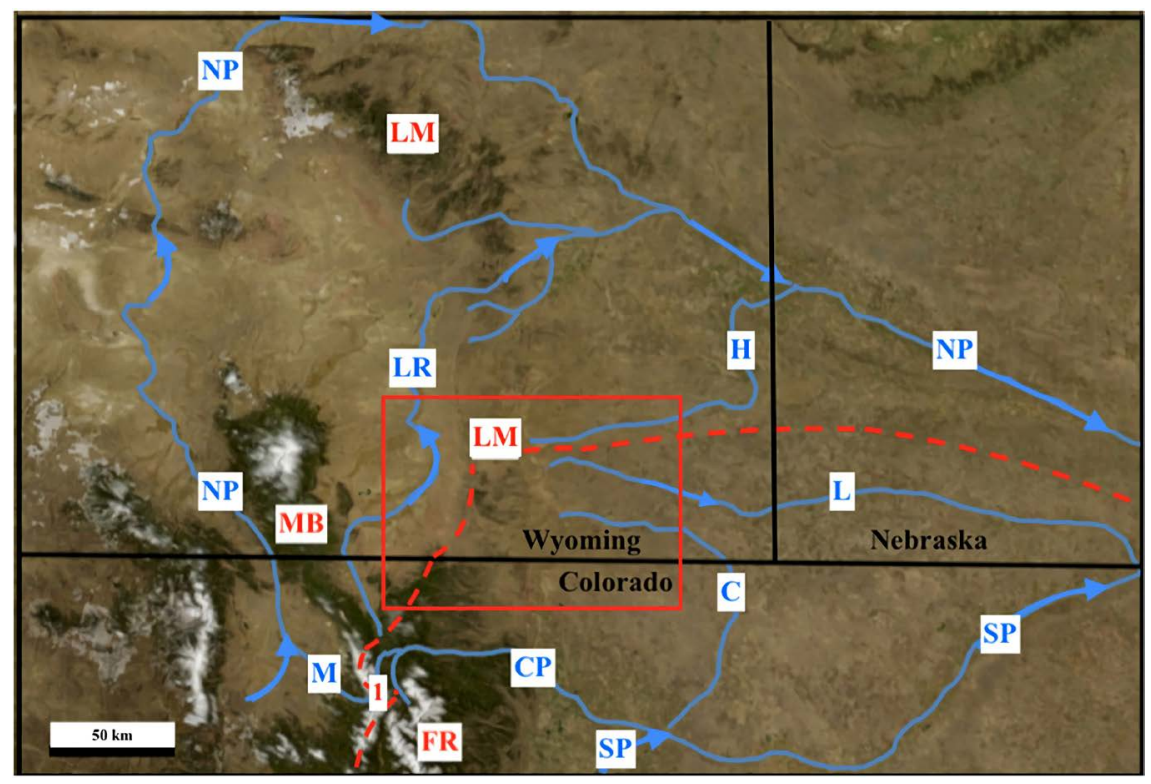

Figure 1. Modified imagery from United States Geological Survey (USGS) National Map website showing study region location (shown in more detail in Figure 2). Red letters: FR: Front Range, LM: Laramie Range, MB: Medicine Bow Mountains. Blue letters: CP: Cache la Poudre River, C: Crow Creek, H: Horse Creek, L: Lodgepole Creek, LR: Laramie River, M: Michigan River, SP: South Platte River. The red number 1 shows the Cameron Pass location.

system with subsequent regional uplift initiating a new erosion cycle that at least partially excavated the intermontane basins to recreate at least some of the former Eocene topography. Such an interpretation does not explain why the North Platte River flows from northern Colorado into central Wyoming as a north-oriented river and then turns in a southeast direction or why the Laramie River flows in a north direction before turning in an east and northeast direction to join the southeast-oriented North Platte River. Geomorphologists abiding by accepted paradigm rules treat those large-scale river direction changes as (shelved) anomalous evidence. Yet, geomorphology is the science that studies "the classification, description, nature, origin, and development of present landforms and their relationships to underlying structures, and of the history of geologic changes as recorded by these surface features" [2], and the North Platte River and Laramie River direction changes represent large-scale evidence a regional geomorphology paradigm should be able to explain. For this reason, a new paradigm has emerged with a defining rule requiring almost all valleys within the present-day Missouri River drainage basin to have eroded headward across or along massive south and southeast-oriented floods.

The new paradigm defining rule forces recognition of a large continental ice sheet that deeply eroded the continent (the accepted paradigm does not recognize deep continental ice sheet erosion) and heavy enough to cause crustal warping that raised entire regions and mountain ranges as immense meltwater floods flowed across them (the accepted paradigm attributes regional and mountain range uplift to other causes and to have occurred prior to any North Amer- 
ican continental ice sheets). The new paradigm implies Wyoming and Colorado regional and mountain range uplift occurred as massive south-oriented continental ice sheet melt water floods flowed across the region with Colorado mountain range uplift blocking, diverting, and reversing the floods, which were also beheaded and reversed in sequence (from east to west) by headward erosion of the southeast-oriented North Platte River valley. South-oriented flood flow on both the north-oriented Laramie and North Platte River alignments that had been flowing to the actively eroding Colorado River valley was blocked by rising Colorado mountain ranges with the south-oriented water on the what is today the north-oriented North Platte River alignment forced to flow to the Laramie Basin where it could spill in an east direction across the rising Laramie Range so as to reach the actively eroding North and South Platte River valleys. At the same time headward erosion of the southeast-oriented North Platte River valley was beheading and reversing south-oriented flood flow across the northern Laramie Range while south-oriented flood flow continued to move into northern Colorado along what is today the north-oriented North Platte River alignment where the water was forced to flow in an east direction along the present-day northwest- and west-oriented Michigan River valley route and in a north direction along the Cameron Pass alignment to reach the Laramie Basin and then to spill eastward. The new paradigm explains the North Platte and Laramie River routes while the accepted paradigm does not, and the question arises, how do the two paradigms explain the more detailed southeast Wyoming drainage features shown in Figure 2?

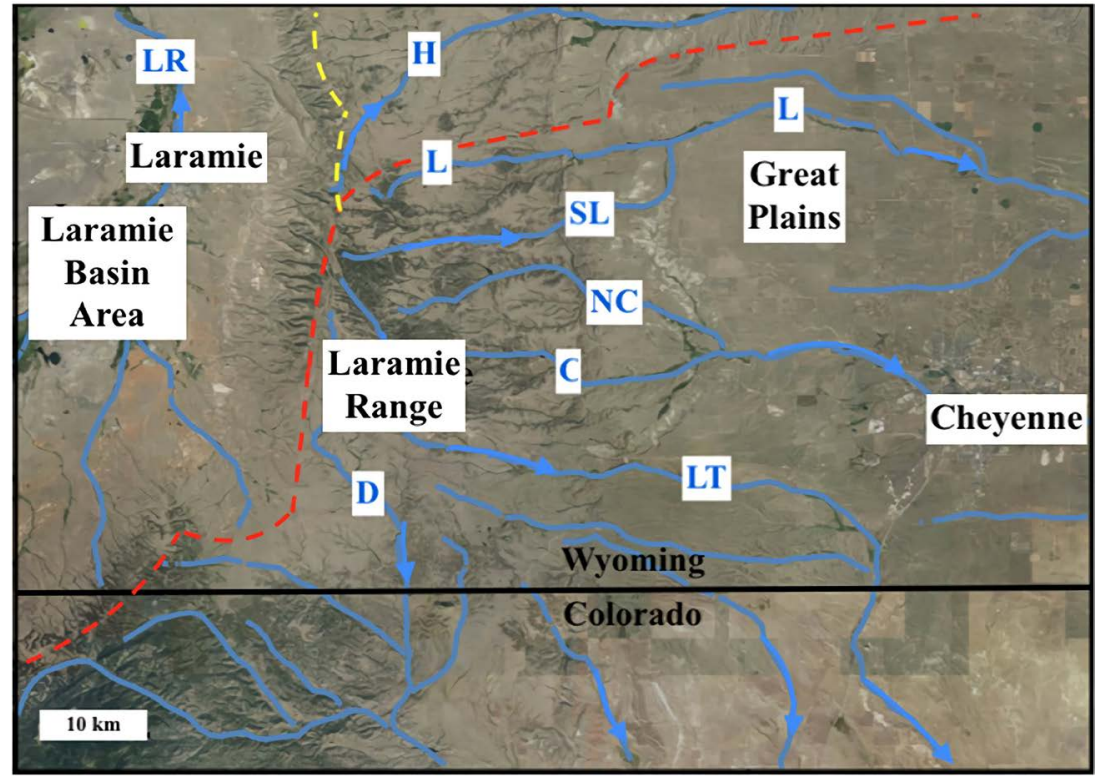

Figure 2. Modified imagery from USGS National Map website showing study area between Cheyenne and Laramie, Wyoming. Drainage routes are identified by letters: C: Crow Creek, D: Dale Creek, H: Horse Creek, L: Lodgepole Creek, LR: Laramie River, LT: Lone Tree Creek, NC: North Crow Creek, SL: South Lodgepole Creek. Red dashed line shows North Platte River-South Platte River drainage divide. The yellow dashed line shows the Laramie River-Horse Creek drainage divide. 


\subsection{Geographic Setting}

The "Gangplank" is a narrow strip of Tertiary sediments located in Figure 2 between the Crow and Lone Tree Creek drainage basins where it is possible to travel up a gradual slope without interruption from the Great Plains to the Laramie Range crest and is today a major railroad and highway transportation route [3], yet erosional details describing how the Gangplank was formed have never been well-described. Crow and Lone Tree Creeks after flowing from near the Laramie Range crest in easterly directions onto the Great Plains eventually turn in south directions to join the South Platte River. Immediately west of Lone Tree Creek headwaters and of some Crow Creek headwaters are south-oriented Dale Creek headwaters (which for a distance flow almost along the Laramie Range crest) with Dale Creek also flowing to the South Platte River. To the north of the south-oriented Dale Creek headwaters other (southeast-oriented) Crow Creek headwaters, east-oriented Lodgepole Creek headwaters and northeast-oriented Horse Creek headwaters also originate near the Laramie Range crest. The steeper Laramie Range west slope is drained by numerous shorter west-oriented drainage routes leading into the Laramie Basin where they join the Laramie River, which after flowing in a north direction turns in an east and northeast direction as it flows through a deep canyon across the Laramie Range to eventually join the southeast-oriented North Platte River.

To the south and southwest of the southern Laramie Range are the Colorado Front Range and other northern Colorado mountain ranges. The North Platte River originates in a mountain surrounded basin (known as North Park) which is surrounded by late Oligocene volcanic fields [4] and from Colorado flows in a north direction to central Wyoming where it turns around the Laramie Range northwest end to flow in an east and southeast direction into Nebraska. Southeast-oriented South Platte River headwaters and tributaries (to the south of Figure 1) flow through another mountain enclosed basin (known as South Park) before making an abrupt turn to flow in a north-northeast direction through mountain canyons and then in a northeast direction onto the plains and into Figure 1 map area. To the east of Figure 1 the South Platte River joins the North Platte River to form the east-oriented Platte River. Today Cameron Pass links northwest-oriented Michigan River headwaters (a North Platte River tributary) with north- and northeast-oriented Joe Wright Creek (flowing to the Cache la Poudre River and then the South Platte River) and is also linked by through valleys with Laramie River headwaters. Just to the south of Cameron Pass and the Joe Wright Creek and Cache La Poudre River headwaters are abandoned valleys (now mountain passes) leading to the Colorado River headwaters.

\subsection{Previous Work}

The most significant previous work (related to this paper) was done over many years and resulted in the detailed topographic maps now available at the United States Geological Survey (USGS) National Map website. These paradigm neutral 
topographic maps show modern-day drainage routes and can be used to identify drainage divides and divide crossings (low points or abandoned valleys) where former drainage routes once crossed what are now drainage divides. Also identifiable on these maps are features such as valley and drainage route orientations, barbed tributaries, water and wind gaps, hogback ridges, erosional escarpments, and similar features all of which are essential when trying to reconstruct a region's geomorphic history. Geologic maps such as the Ver Ploeg and Boyd Geologic Map of the Laramie 30' $\times 60^{\prime}$ quadrangle [5] also show other paradigm neutral information such as surface bedrock units and structural features that may be important when trying to understand the region's drainage and erosional history.

The Gangplank is where the Cheyenne Tablelands Miocene Ogallala Formation "forms a smoothly ascending ramp up onto the Laramie Range" [3] (p. 203) and laps onto Precambrian bedrock units. Atwood and Atwood [6] (p. 971) state "the transition from the plains to the mountains is almost imperceptible. There is no pronounced change or break in the topography". Similar Ogallala sediments form the most common surface bedrock unit found throughout the southeast Wyoming Cheyenne Tablelands region, which is located to the east of the Laramie Range and between the southeast-oriented North Platte River and the northeast-oriented South Platte River. Mears [7] (p. 451) notes "the late Miocene Ogallala Formation reflects a major change in depositional environments. ...The dominantly fluvial Ogallala deposits, which overlie a pronounced erosion surface, are mostly relatively coarse clastics in deep channel fills of shifting stream systems. Some of the clasts were derived from the distinctive pink Sherman Granite, dark anorthosites and other Precambrian rocks in the Laramie Range, however a notable component are Precambrian rock types from the Colorado Front Range. The most distinctive clasts are rhyolitic cobbles, pebbles, and granules from late Oligocene volcanic fields in Colorado" which implies they must have been transported by northeast-oriented streams crossing what are today the Laramie Basin and the Laramie Range core. In terms of the Laramie Range core area immediately to the west of the Gangplank Blackwelder [8] (p. 435) states "the surface is in reality a plain of denudation, now more or less dissected. This surface passes with very little change across the outcrops of many different kinds of rock. Schists, gneisses, porphyries, and gabbros are alike worn to a common level; and so slightly do they affect the details of the topography that surface forms are of doubtful value in mapping the outcrops of the different rock formations".

Several workers have tried to explain the above observations from an accepted paradigm perspective. For example, McMillan et al. [9] determined the Cheyenne Tablelands have been tilted $680 \mathrm{~m}(815-410 \mathrm{~m})$ up to the west and suggest (p. 66) that "the post depositional changes in the slope of Ogallala stream channels suggest that broad-wavelength tectonic forces have played a dominant role in the late Cenozoic history of the region", but do not address how alluvium from northern Colorado volcanic fields reached those Cheyenne Tablelands stream 
channels. To reach the Cheyenne Tablelands streams from the Colorado late Oligocene volcanic fields must have crossed what are today the Laramie Basin and the Laramie Range, which requires a very different regional topography than what exists today. Many accepted paradigm interpretations suggest intramontane basins (like the Laramie Basin) were filled with great thicknesses of middle Tertiary sediments and Pelletier [10] argues that increased late Miocene and Plio-Quaternary snowmelt eroded the intramontane basins and caused downstream deposition, which (p. 5) "is broadly consistent with the magnitude timing, and spatial distribution of the Ogallala Formation". However, Fan et al. [11] state "when and how the central Rocky Mountains (Rockies) of western North America gained modern topography remain controversial questions" and go on to "suggest that the region underwent differential uplift to form relief similar to that of today before earliest Oligocene time", but do not explain how Colorado late Oligocene volcanic alluvium reached the Cheyenne Tablelands. These and other investigators who followed accepted paradigm rules also fail to demonstrate how their hypotheses explain the detailed topographic map drainage system evidence.

From a new paradigm perspective Clausen [12] (p. 35) used topographic map evidence to demonstrate how a diverging and converging complex of bedrock-walled canyons now crossing the Laramie Range (where the Laramie River crosses the Laramie Range) was eroded by multiple streams of water that "must have diverged in the Laramie Basin from the north-oriented Laramie River to enter the Laramie Range before converging in or east of the Laramie Range". In a subsequent paper dealing with the Laramie Range northern and northwest sections Clausen notes [13] (p. 739) immense south-oriented floods "flowed in large complexes of diverging and converging channels crossing what at that time was a rising Laramie Mountains area with the North Platte valley eroding headward along the northern Laramie Mountains northeast flank and the around Casper Mountain [at the Laramie Mountains' northwest end] to capture, behead, and reverse those south-oriented flood flow channels". In other words, those two papers imply large south-oriented floods entering what is today the Laramie Basin were beheaded and reversed. In a more recent paper [14] Clausen (p. 53) states "south-oriented flood flow moving on what is now the north-oriented North Platte River alignment (which prior to its reversal had been moving water across what are now high mountain passes to the Colorado River drainage basin and to the Laramie and Cache la Poudre Rivers)" and implies huge south-oriented floods flowed around the Medicine Bow Mountains south end on a route that eventually eroded Cameron Pass so as to flow in a north direction and to enter the Laramie Basin area as large north-oriented floods.

\section{Research Method}

The study reported here used topographic maps, imagery, and tools available at the USGS National Map website and also the cited geologic maps and literature. 
Detailed topographic maps were used to study the drainage divide along the Laramie Range crest between the north-flowing Laramie River (in the Laramie Basin) and east- and south-flowing South Platte River tributaries (i.e. Dale, Lone Tree, Crow, and Lodgepole Creeks) to identify divide crossings (or low points) where water had once flowed from what is today the much lower (in elevation) Laramie Basin across the Laramie Range to deposit what are now extensive sheets of Ogallala Formation located on the plains to the east. Next drainage divides surrounding the south-oriented Dale Creek headwaters (located along the Laramie Range crest) were studied to determine if there is evidence the Dale Creek valley had been eroded headward across multiple closely-space streams of east-oriented (flood?) flow. Third, the Dale Creek drainage divide with east-oriented Lone Tree and Crow Creek headwaters was investigated to determine if headward erosion of the Dale Creek valley had beheaded east-oriented flow that had been moving to what are now the Lone Tree and Crow Creek drainage basins and also to determine the nature of that flow. Fourth, the Gangplank itself was studied to determine how it was formed between the Crow Creek and Lone Tree Creek drainage basins. In addition, topographic maps covering North Platte and Laramie River headwaters areas were studied to determine how previously reported distinctive volcanic alluvium (described as Oligocene in age) had been transported from northern Colorado across what are now the Laramie Basin and the Laramie Range to be deposited in Ogallala Formation sediments found to the east of the Laramie Range. The observed topographic map evidence was explained to extent possible by previously published accepted paradigm hypotheses and also from the context of the new paradigm defining rule, which requires all major valleys within the present-day Missouri River drainage basin to have been eroded across or along immense south- and southeast-oriented floods.

\section{Results}

\subsection{Laramie River-Lodgepole Creek Drainage Divide}

Figure 3 shows a Laramie River-Lodgepole Creek drainage divide area about 2 kilometers north of where a major divided highway crosses the Laramie Range. The Laramie River flows in a north direction through the Laramie Basin (to the west of the figure) before turning in an east and northeast direction to cross the Laramie Range and join the North Platte River. Lodgepole Creek flows in east direction into Nebraska before turning in a south direction to join the South Platte River while Horse Creek (located to the north of Lodgepole Creek) after flowing onto the plains in an east direction turns in a north direction to join the North Platte River. Locations marked by numbers 1 and 2 identify divide crossings (low points) along the Laramie Range crest. Running water moving in one direction or the other eroded those divide crossings. Note how west oriented valleys draining from those two divide crossings converge in the figure while the North and Middle Branch Lodgepole Creek valleys converge to the east of the 


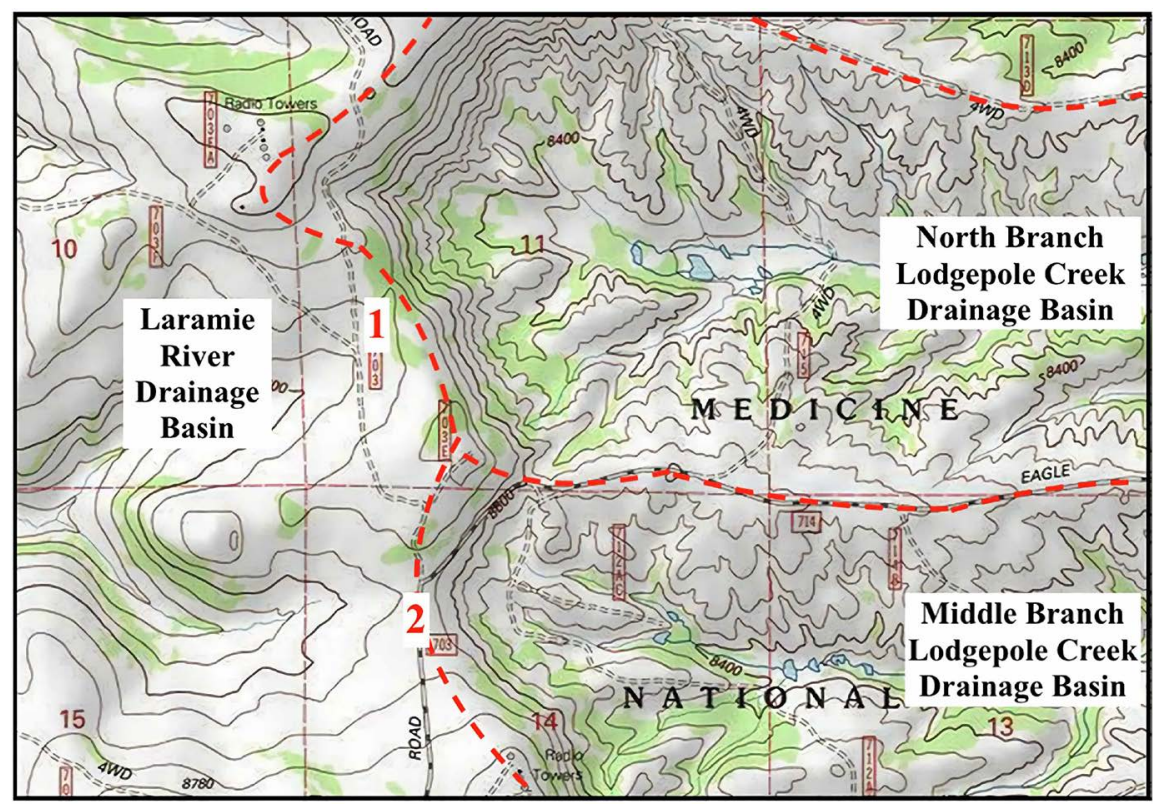

Figure 3. Modified topographic map from USGS National Map website showing the Laramie River drainage divide with the North and Middle Branches of Lodgepole Creek. Unlabeled drainage area in the figure northeast corner is the Horse Creek drainage basin. Red dashed lines show drainage divides. Red numbers identify divide crossings discussed in the text. The contour interval is 40 feet ( 12 meters). Grid lines outline sides of squares 1 mile (1.6 kilometers) in length.

figure suggesting the water once flowed in diverging and converging channels (common in flood formed anastomosing channel complexes). Similar divide crossings are found to the north of the figure along the Laramie River-Horse Creek drainage divide and to the south of the figure along the Laramie River-South Branch Lodgepole Creek drainage divide suggesting a large flood formed anastomosing channel complex once crossed what is now the Laramie Range crest ridge. While easily seen on the detailed topographic maps the evidence for a large flood-formed anastomosing channel complex crossing what is now the Laramie Range has not been previously described or explained.

Today, the Laramie River-Lodgepole Creek (and Horse Creek) drainage divide roughly follows the top of the Laramie Range's steeply dipping west-facing slope (mapped as "Pennsylvanian-Permian Casper-Fountain Formation undivided" [5]) leading down to the Laramie Basin floor more than 400 meters below, while the somewhat more gradual east-oriented slope leads to the even lower elevation Great Plains, meaning it would be impossible today for floods moving in either direction to reach the Laramie Range crest. At least two lines of evidence suggest east-oriented floods eroded the divide crossings now notched into the Laramie Range crest ridge. First, the Ogallala Formation sediment composition in the Cheyenne Tablelands to the east includes alluvium derived from the Laramie Range and also from Colorado mountain regions to the southwest. Second, east-oriented Lodgepole Creek headwaters (to the east of numbers 1 and 2) begin in escarpment-surrounded basins (or head cuts) and downstream valleys carved in 
Precambrian granite bedrock suggesting erosion by substantial east-flowing streams of water. The question then arises, how did large east-oriented volumes of water move from the much lower Laramie Basin across what is now a 400 -meter or higher mountain range?

Any accepted paradigm interpretation of the Laramie Range crest ridge divide crossings must address interpretations such as the Fan et al. [11] (p. 547) suggestions that "the region underwent differential uplift to form relief similar to that of today before earliest Oligocene time" and "the central Rockies and adjacent Great Plains underwent uplift during the late Eocene, and have not undergone any large magnitude $(>500 \mathrm{~m})$ uplift since that time". If correctly interpreted the Laramie Basin must have been filled during Oligocene and Miocene time with sedimentary materials to a level at least 400 meters above the present-day basin floor, which is precisely what many previous investigators have suggested. For example, Mears [15] (p. 609) in a literature review describes "renewed basin filling in the latest Eocene [and the] rising level of Oligocene and then Miocene deposits eventually lapped across the lower segments of the crystalline-cored uplands that finally had been eroded down to broad subsummit surfaces surmounted by residual hills and peaks". While such an accepted paradigm interpretation provides a way for east-oriented streams of water to have reached the Laramie Range crest the interpretation leaves unanswered how 400 or more meters of hypothesized Oligocene and Miocene sediments were completely removed from what is now the Laramie Basin since the Geologic Map of Wyoming [16] in the Laramie Basin area to the west shows few, if any remnants of that hypothesized 400 meters of Oligocene and Miocene sediment fill (although such sediments are found in northern Laramie Range valleys [17]).

In contrast the new paradigm requires Wyoming and Colorado regional and mountain uplift to have occurred while south- and southeast-oriented continental ice sheet melt water floods flowed across the region and implies the continental ice sheet weight was responsible for crustal warping that raised the region and mountain ranges and does not require 400 or more meters of Oligocene and Miocene sediments to have filled the Laramie Basin. Instead the new paradigm explanation requires massive and prolonged south-oriented floods to have flowed across the region with regional and mountain uplift blocking the flood flow in Colorado and forcing the south-oriented water flowing to the west of the rising Medicine Bow Mountains to make a $\mathrm{U}$ turn around the rising Medicine Bow Mountains' southern end and to flow in a north direction into the Laramie Basin, only to be met by south-oriented floods still reaching the area from the north and northwest, which forced the floodwaters to spill in an eastward direction across the rising Laramie Range. As Laramie Range uplift progressed east-oriented canyons eroded headward from the actively eroding North Platte River valley and captured east-oriented flood flow moving from the Laramie Basin with south-oriented flood flow channeled into the North Laramie River canyon and north-oriented flood flow channeled into canyons associated with the present-day Laramie River canyon [12]. 


\subsection{Middle Crow Creek Headwaters Area}

In Figure 4 a major east-west highway uses the divide crossing seen at the red number 3 to cross the Laramie Range crest at a point near the Laramie River, Crow Creek, and Lodgepole Creek triple drainage divide. Shallow divide crossings, such as seen at the number 4 provide evidence water once also flowed between the present-day Lodgepole and Crow Creek drainage basins. To the south of the figure southeast-oriented Middle Crow Creek gradually turns in more of an east direction before eventually joining with North Fork Crow Creek and South Crow Creek to form east-oriented Crow Creek (which eventually turns in a south direction). North Fork Crow Creek headwaters begin to the east of the Sherman Mountains, which are a north-northwest to south-southeast oriented granite ridge located to the east and southeast of Figure 4. The Sherman Mountains' crest elevation is comparable in height to the elevations found along the Laramie Range crest ridge and divide crossings of varying depths suggest multiple streams of water once crossed what is now the Middle Crow Creek-North Fork Crow Creek drainage divide. To the south of Figure 4 Dale Creek originates on the Laramie Range crest and flows in a south direction near and parallel to the Laramie River-South Platte River drainage divide. In brief, south-oriented Dale Creek just like Middle Crow Creek has carved a deep south-oriented valley into the Laramie Range's high elevation granite surface.

To the southeast of Figure 4 southeast-oriented South Crow Creek and Lone Tree Creek headwaters originate close to each other along a beveled off granite surface at the top of the east side of the south-oriented Dale Creek valley. Drainage routes, divide crossings, and beveled off surfaces found in this Laramie Range crest area suggest headward erosion of the deeper southeast-oriented Middle

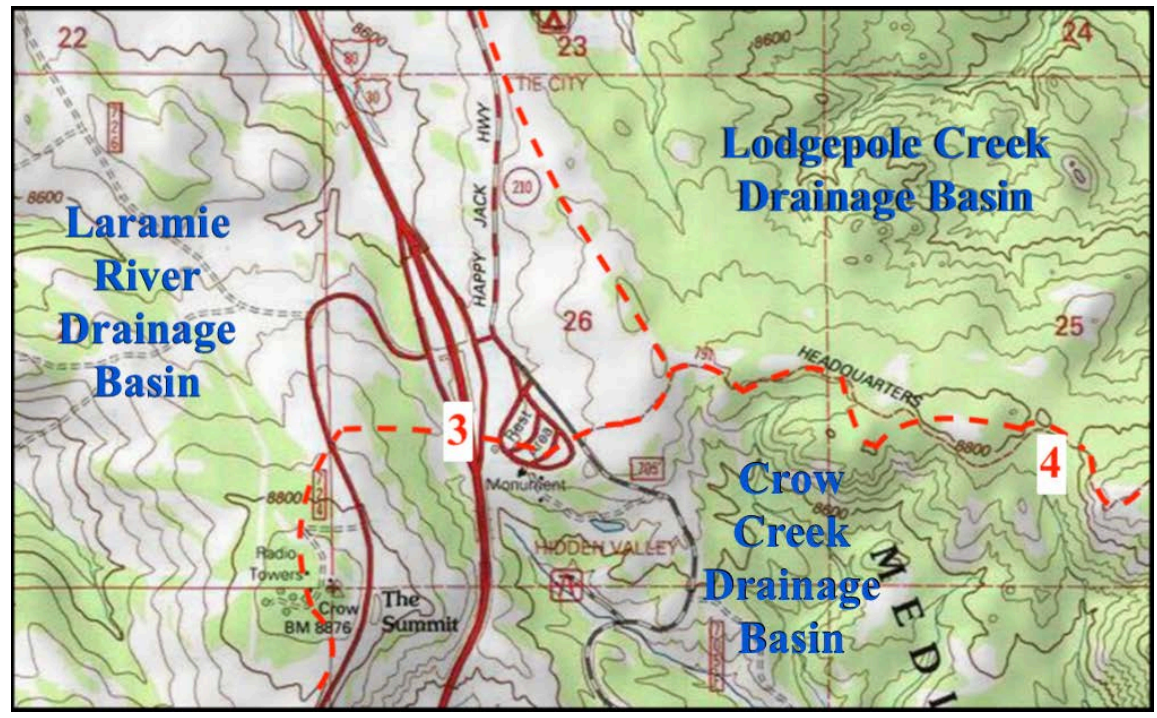

Figure 4. Modified topographic map from USGS National Map website showing Laramie River-Lodgepole Creek-Crow Creek drainage divides. Red dashed lines show drainage divides. Red numbers identify divide crossings discussed in the text. Contour interval is 40 feet (12 meters). Grid lines outline sides of squares 1 mile (1.6 kilometers) in length. 
Crow Creek valley first captured east-oriented flood flow moving in a large east oriented anastomosing channel complex across what are now the Sherman Mountains to the North Fork Crow Creek drainage basin with headward erosion of the deeper south-oriented Dale Creek valley next capturing the east- and southeast-oriented flood flow (which may have been moving as large sheets of water) to what are now the Lone Tree Creek and South Crow Creek headwaters areas and then capturing some of the east-oriented flood flow moving into what at that time was probably the actively eroding southeast-oriented Middle Crow Creek valley. Headward erosion of the east-oriented Lodgepole Creek drainage system must have occurred at about the same time and also captured south-oriented flood flow moving toward what is now the Crow Creek drainage basin. Drainage routes and divide crossings discussed here suggest numerous stream captures occurred as the present-day drainage system developed, but Bishop [18] (p. 449) argues from the accepted paradigm perspective, "The key process in stream capture, namely, drainage head retreat, is difficult to envisage as a normal part of drainage net evolution [and]... Stream capture may therefore be a relatively rare event in drainage net evolution". In other words, these drainage routes, valleys, and divide crossings as observed on topographic maps are difficult to explain in terms of processes occurring today, but can be explained (like in Figure 3 and Figure 4 map evidence) in the context of immense east-oriented floods flowing across the region.

\subsection{South Fork Crow Creek-Lone Tree Creek Drainage Divide}

Figure 5 shows an area located about 17 kilometers (as the crow flies) to the southeast of Figure 4 and is at the eastern edge of the Laramie Range Precambrian

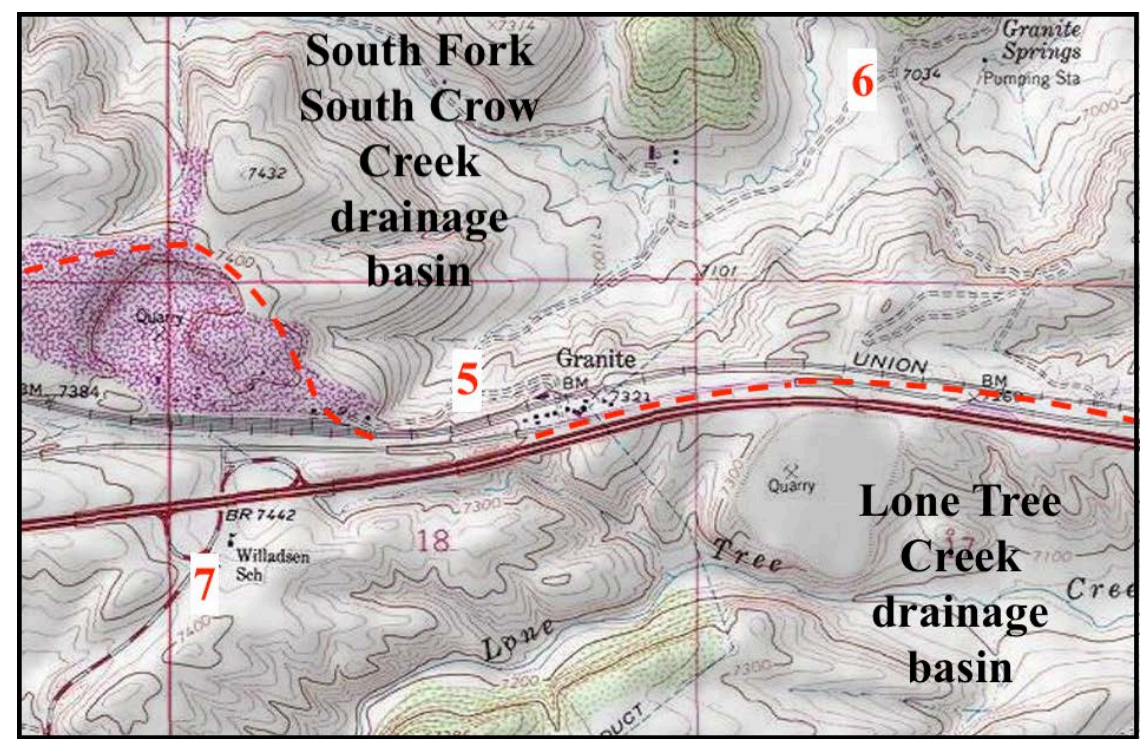

Figure 5. Modified topographic map from USGS National Map website showing where the highway and railroad smoothly cross from Tertiary bedrock onto the Laramie Range Precambrian granite bedrock core. Red numbers identify locations discussed in text. Red grid lines are 1 mile (1.6 kilometers apart) and the contour interval is 20 feet (6 meters). 
bedrock core. The east-west divided highway and railroad are located on the South Fork South Crow-Lone Tree Creek drainage divide (shown by the dashed red line) and the purple stippled area is a large granite quarry. To the east of the town of Granite and south of the highway is another quarry where a narrow outcrop of mapped Paleozoic sediments [5] is also mined. To the east of that narrow outcrop the highway and railroad are located on Miocene Ogallala Formation sediments which form the Gangplank. The geologic map [5] shows some of the South Fork South Crow Creek valley as being cut into Oligocene White River Formation (which underlies the Ogallala Formation and which is abundant in areas to the east of the Laramie Range). Note how the highway and the railroad use the South Fork Crow-Lone Tree Creek drainage divide to transition from the beveled off Laramie Range Precambrian bedrock core onto the Gangplank Miocene sediment ramp.

Notice also how the divided highway and railroad cross a shallow divide crossing at number 5 on embankments while the road between them dips below the darker contour line. That divide crossing was eroded by southeast-oriented water flowing from the South Fork South Crow Creek drainage basin into the Lone Tree Creek drainage basin (probably flowing in a southeast direction across an unlabeled divide crossing located north of the granite quarry). Number 6 identifies a deeper divide crossing, which links east- and north-oriented South Fork South Crow Creek with northeast-oriented Spring Branch headwaters which flow to South Fork South Crow Creek just to the northeast of Figure 5. The divide crossing at number 7 suggests water once flowed in a northeast direction from the Lone Tree Creek drainage basin into the South Fork South Crow Creek drainage basin. These and other divide crossings suggest the Crow and Lone Creek drainage systems originated as components of the same east-oriented anastomosing channel complex, with headward erosion of a south-oriented valley capturing the south half (now the Lone Creek drainage basin) while the north half is now the Crow Creek drainage basin.

\subsection{Anastomosing Channels in the Crow and Lone Tree Creek Area}

Figure 6 provides a topographic map of a Crow Creek-Lone Tree Creek drainage divide area about 8 kilometers southeast of Figure 5. Numbers 8 and 9 identify divide crossings along the Crow Creek-Lone Tree Creek drainage divide where water apparently once flowed from the Lone Tree Creek valley into the Corlett Creek valley. The red dashed line shows the drainage divide between east-oriented Lone Tree Creek and an east-oriented Crow Creek tributary (to the northeast of the figure Corlett Creek joins northeast-oriented Clear Creek, which joins east-oriented Crow Creek). These and other divide crossings support the interpretation that the Crow and Lone Tree Creek drainage systems originated as components of the same east-oriented anastomosing channel complex. To the north and south of the Gangplank the smooth transition from the plains to the Laramie Range bedrock core is lost as erosion has exposed hogback ridges and 


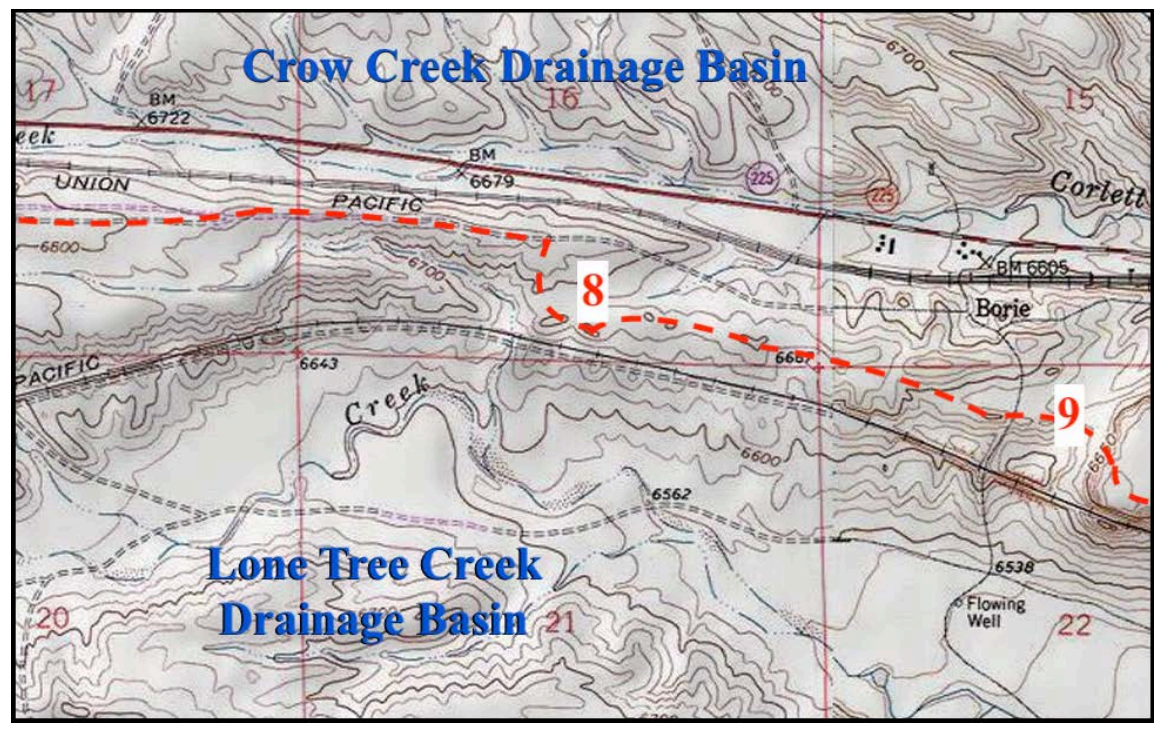

Figure 6. Modified topographic map from USGS National Map website showing how the Gangplank roughly follows the Crow Creek-Lone Tree Creek drainage divide and is crossed by shallow divide crossings at the red numbers 1 and 2 . The red dashed line shows the drainage divide locations and the contour interval is 20 feet (6 meters). Red grid lines are 1 mile (1.6 kilometer) apart.

bedrock units underlying the Miocene age Ogallala Formation (such as the Oligocene age White River Formation) [5]. The greater local relief makes the divide crossings easy observe on detailed topographic maps and evidence for linkages between various east-oriented drainage routes is just as good or better than in the Gangplank area. To the north of the Gangplank divide crossings suggest the Crow and Lodgepole Creek drainage basins were once intertwined and a case can also be made that water once flowed at several localities between the Lodgepole and Horse Creek drainage basins.

To the east of Figure 6 Lone Tree Creek turns from flowing in an east direction to flow in more of a south direction and to join the northeast-oriented South Platte River (see Figure 2). Babcock and Bjorklund [19] state (p. 9) Lone Tree Creek and two of its downstream tributaries formerly "flowed eastward across the area and joined Crow Creek in the vicinity of Carpenter, but a stream working northward [from the South Platte River valley]... captured the [three creeks] and established the present drainage system". Today the east-oriented Porter Creek valley begins near where Lone Tree Creek makes its turn to the south and joins Crow Creek after it has turned from flowing in an east direction to flow in a south direction and to eventually join the South Platte River. Near where Crow Creek turns in a south direction are east-oriented headwaters of Lodgepole Creek tributaries with Lodgepole Creek also eventually turning in a south direction. Today detailed topographic maps suggest east-oriented drainage systems now originating on the Laramie Range crest and flowing across the Gangplank area and the larger Cheyenne Tablelands region must have originated as valleys eroded headward from the deeper North and South Platte River 
valleys across a large east-oriented anastomosing channel complex, although to date researchers following accepted paradigm rules for whatever reason have not considered the flood flow evidence important enough to address.

\section{Discussion}

Lodgepole, Crow, Lone Tree, and Dale Creek flow to the northeast-oriented South Platte River, although at very different locations (see Figure 1 and Figure 2 ) and the question arises, how can these four east-oriented creeks originate near each other in the same Laramie Range crest area and now flow on very different routes to reach the South Platte River? Investigators following accepted paradigm rules have not answered this question and imply today's drainage system developed over long periods of time in response to a variety of climatic conditions and tectonic movements (without providing any details). In contrast the new paradigm requires the northeast-oriented South Platte River and the four creek valley systems to have eroded headward along or across immense south- or southeast-oriented floods (some of which were probably being diverted to flow in an east direction to reach an actively eroding and much deeper east-oriented Platte River valley (with the deep northeast-oriented South Platte River and southeast-oriented North Platte River valleys then eroding headward from it). South Platte River valley headward erosion would have proceeded in a southwest direction so Lodgepole Creek valley headward erosion would have been initiated first, Crow Creek valley headward erosion second, Lone Tree Creek valley headward erosion third, and Dale Creek valley headward erosion fourth. Assuming each valley eroded headward across and then along the same massive floods all four creek valleys could have eroded headward to capture different segments of the same large east-oriented anastomosing channel complex.

In 1927 J Harlan Bretz [20] used the presence of a large anastomosing channel complex as one line of evidence when he presented his case for flood erosion of the Washington State Channeled Scabland region to what at that time was a skeptical audience and the divide crossings described here (and elsewhere in the Cheyenne Tablelands) are difficult to explain except in the context of a large east-oriented flood formed anastomosing channel complex. Massive east-oriented floods must have flowed in diverging and converging channels from what is now the Laramie Basin area across what is now the Laramie Range Precambrian bedrock core and across what are now the Crow Creek, Lone Tree Creek and Lodgepole Creek drainage basins, with headward erosion of the deep south-oriented Lodgepole Creek valley segment first capturing the east-oriented flood flow, headward erosion of the south-oriented Crow Creek valley segment next capturing east-oriented flood flow moving to the south of the actively eroding east-oriented Lodgepole Creek valley system (which was eroding headward from the south-oriented Lodgepole Creek valley segment), headward erosion of the deep south-oriented Lone Tree Creek valley segment capturing east-oriented flood flow which was moving to the south of the actively-eroding east-oriented 
Crow Creek valley system (which was eroding headward from the deep south-oriented Crow Creek valley segment, headward erosion of the south-oriented Dale Creek valley beheading east-oriented flood that had been moving to the what are now the Lone Tree Creek and South Crow Creek drainage basins, and finally Laramie Range uplift ended flood flow across the Gangplank area. Such an explanation accounts for the Lodgepole, Crow, Lone Tree, and Dale Creek drainage route locations, orientations, and direction changes seen today. At the same time east-oriented flood flow moving in diverging and converging channels across what is today the Horse Creek drainage basin (further to the north) was captured by headward erosion of a north-oriented valley from the what must have been an actively eroding southeast-oriented North Platte River valley to create what is today the North Platte River-South Platte River drainage divide between the Horse and Lodgepole Creek drainage basins and the Horse Creek direction change seen today (see Figure 1 and Figure 2).

While the evidence for the above described sequence of valley erosion is easily seen on detailed topographic maps the accepted paradigm does not provide a water source large enough to account for the described erosion events (especially since most accepted paradigm interpretations require vast quantities of water from an unknown source to have also completely or almost completely removed 400 or more meters of hypothesized Oligocene and Miocene sediments that once filled the Laramie Basin. That sediment fill is required in any accepted interpretation of the map evidence to explain how east-oriented floodwaters could reach the Cheyenne Tablelands region). At best the accepted paradigm interpretations can only offer vague statements about how climatic changes may have increased precipitation and runoff or that much heavier snowfall in mountains to the west resulted in large east-oriented floods. While perhaps not impossible trying to explain the modern-day drainage features, such as the North Platte River, Laramie River, Horse Creek, Lodgepole Creek, Crow Creek, and Lone Tree Creek direction changes and the absence of almost all Laramie Basin Oligocene and Miocene sediments from the accepted paradigm perspective is extremely complicated so a simpler explanation almost certainly exists. The new paradigm offers a simpler explanation that explains North Platte River, Laramie River, Horse Creek, Lodgepole Creek, Crow Creek, and Lone Tree Creek direction changes and the almost complete absence of Laramie Basin Oligocene and Miocene sediments. From the new paradigm perspective detailed drainage system features such as the Lone Tree, Crow, Lodgepole, and Horse Creek direction changes are like pieces of a large picture puzzle that when correctly assembled fit snuggly together. However, the new paradigm also requires a very different middle and late Cenozoic geologic and glacial history than what geologists working from the accepted paradigm perspective have described and resistance to the new paradigm is to be expected.

\section{Conclusions}

Geomorphologists have considered the Gangplank area to be an interesting re- 
search subject at least since the building of the first transcontinental railroad and detailed topographic maps of the region have been available for at least 50 years. Yet, in spite of being a well-known region and of having excellent topographic map coverage accepted paradigm rules and commonly accepted interpretations have prevented most geomorphologists from trying to explain significant drainage features such as the Crow Creek-Lone Tree Creek drainage divide (in other words the Gangplank) and the Horse, Lodgepole, Crow, and Lone Tree Creek direction changes. Further, evidence that large volumes of water once flowed across the Laramie Range and previous interpretations have caused geomorphologists abiding by accepted paradigm rules to propose that more than 400 meters of Oligocene and Miocene sediments once filled the Laramie Basin even though few if any of those sediments remain in the Laramie Basin today.

In contrast the new paradigm explains Lodgepole, Crow, and Lone Tree Creek direction turns by the sequential headward erosion of south-oriented valleys from an actively eroding northeast-oriented South Platte River valley across the south half of large east-oriented anastomosing channel complex while headward of a north-oriented valley from an actively eroding North Platte River valley across the north half of that same large anastomosing channel complex explains the Horse Creek direction turn. The new paradigm defining rule forces recognition of a continental ice sheet that deeply eroded the underlying bedrock (the accepted paradigm does not recognize such an ice sheet), heavy enough to cause crustal warping that raised regions and mountain ranges as prolonged and massive meltwater floods flowed across them (the accepted paradigm attributes regional and mountain range uplift to other causes), and of sufficient size and duration to produce immense and prolonged melt water floods able to deeply erode what is now the entire Missouri River drainage basin (accepted paradigm rules do not permit continental sheet melt water to have reached, much less to have deeply eroded, much of the Missouri River drainage basin, including this paper's study region). However, the new paradigm also forces a fundamentally different interpretation of middle and late Cenozoic glacial and geologic history than what the accepted paradigm describes and as Kuhn [1] points out scientific disciplines do not easily change paradigms and much future work is needed to demonstrate how the new paradigm explains additional easy to observe evidence.

\section{Acknowledgements}

During the mid 1960s Arthur Strahler, then at Columbia University, and Brainerd Mears, Jr., then at the University of Wyoming, introduced the author of this paper to numerous unsolved drainage history problems. Preliminary work leading up to this study was done while employed as a faculty member at Minot State University (North Dakota) where other faculty members, library staff, and students assisted in providing access to needed topographic maps.

\section{Conflicts of Interest}

The author declares no conflicts of interest regarding the publication of this paper. 


\section{References}

[1] Kuhn, T.S. (1970) The Structure of Scientific Revolutions. 2nd Edition, University of Chicago Press, Chicago, $210 \mathrm{p}$.

[2] Gary, M., McAfee Jr., R. and Wolf, C. L., Eds. (1972) Glossary of Geology. American Geological Institute, Washington DC, 293-294.

[3] Meldahl, K.H. (2011) Rough-Hewn Land: A Geologic Journey from California to the Rocky Mountains. University of California Press, Berkeley, CA, 296 p.

[4] Stevens, T.A. (1975) Middle Tertiary Volcanic Field in the Southern Rocky Mountain. In: Curtis, B.F. (Ed.), Cenozoic History of the Southern Rocky Mountains, Geological Society of America Memoir 144, 75-94.

https://doi.org/10.1130/MEM144-p75

[5] Ver Ploeg, A.J. and Boyd, C. S. (2007) Geologic Map of the Laramie 30' × 60' Quadrangle, Albany and Laramie Counties, Southeastern Wyoming: Wyoming Geologic Survey, Map Series MS-77, Scale 1:100,000.

[6] Atwood, W.W. and Atwood Jr., W. W. (1938) Working Hypothesis for the Physiographic History of the Rocky Mountain Region. Bulletin of the Geological Society of America, 49, 957-980. https://doi.org/10.1130/GSAB-49-957

[7] Wayne, W.J., Aber, J.S., Agard, S.S., Bergantino, R.N., Bluemle, J.P., Coates, J.P., Cooley, D.A., Madole, R.F., Martin, J.E., Mears Jr., B., Morrison, R.B. and Sutherland, W.M. (1991) Quaternary Geology of the Northern Great Plains. In: Morrison, R.B., Ed., Quaternary Nonglacial Geology: Conterminous US, The Geology of North America, v. K-2, Geological Society of America, Boulder CO, 441-476.

[8] Blackwelder, E. (1909) Cenozoic History of the Laramie Region, Wyoming. The Journal of Geology, 17, 429-444. https://doi.org/10.1086/621638

[9] McMillan, M.E., Angevine, C.L. and Heller, P.L. (2002) Postdepositional Tilt of the Miocene-Pliocene Ogallala Group on the Western Great Plains: Evidence of Late Cenozoic Uplift of the Rocky Mountains. Geology, 30, 63-66. https://doi.org/10.1130/0091-7613(2002)030<0063:PTOTMP>2.0.CO;2

[10] Pelletier, J.D. (2009) The Impact of Snowmelt on the Late Cenozoic Landscape of the Southern Rocky Mountains, USA. GSA Today, 19, 4-10. https://doi.org/10.1130/GSATG44A.1

[11] Fan, M., Heller, P., Allen, S.D. and Hough, B.G. (2014) Middle Cenozoic Uplift and Concomitant Drying in the Central Rocky Mountains and Adjacent Great Plains. Geology, 42, 547-550. https://doi.org/10.1130/G35444.1

[12] Clausen, E. (2018) Topographic Map Analysis of Laramie Range Bedrock-Walled Canyon Complex and the Goshen Hole Escarpment-Surrounded Basin, Albany and Platte Counties, Southeast Wyoming, USA. Open Journal of Geology, 8, 35-55. https://doi.org/10.4236/ojg.2018.81003

[13] Clausen, E. (2019) Use of Stream and Dismembered Stream Valleys Now Crossing Wyoming's Northern Laramie Mountains to Test a Recently Proposed Regional Geomorphology Paradigm, USA. Open Journal of Geology, 9, 731-751. https://doi.org/10.4236/ojg.2019.911087

[14] Clausen, E. (2020) Use of Topographic Map Evidence from Drainage Divides Surrounding Wyoming's Great Divide Basin to Compare Two Fundamentally Different Regional Geomorphology Paradigms. Earth Science Research, 9, 45-57.

[15] Mears, B. Jr. (1993) Geomorphic History of Wyoming and High-Level Erosion. Geological Survey of Wyoming Memoir No. 5, 608-626.

[16] Love, J.D. and Christiansen, A.C. (1985) Geologic Map of Wyoming. United States 
Geologic Survey, Scale 1:500,000, Wyoming State Geological Survey 2014 Release.

[17] Evanoff, E. (1990) Early Oligocene Paleovalleys in Southern and Central Wyoming: Evidence of High Local Relief on the Late Eocene Unconformity. Geology, 18, 443-446. https://doi.org/10.1130/0091-7613(1990)018<0443:EOPISA >2.3.CO;2

[18] Bishop, P. (1995) Drainage Rearrangement by River Capture, Beheading and Diversion. Progress in Physical Geography. Earth and Environment, 19, 449-473. https://doi.org/10.1177/0309133339501900402

[19] Babcock, H.M. and Bjorklund, L.J. (1956) Ground-Water Geology of Parts of Laramie and Albany Counties, Wyoming, and Weld County, Colorado. United States Geological Survey Water-Supply Paper 1367, 61 p.

[20] Bretz, J.H. (1927) Channel Scabland and the Spokane Flood. Washington Academy of Science Journal, 17, 200-211. 